\title{
7. BIOSTRATIGRAPHIC SUMMARY OF DSDP LEG 55: EMPEROR SEAMOUNT CHAIN
}

\author{
Itaru Koizumi, College of General Education, Osaka University, Japan \\ Arif Butt, Institut für Geologie und Paläontologie, Universität Tübingen, Tübingen, F. R. Germany \\ Hsin Yi Ling, Department of Geology, Northern Illinois University, Dekalb, Illinois \\ and \\ Toshiaki Takayama, College of Liberal Arts, Kanazawa University, Kanazawa, Japan
}

\section{INTRODUCTION}

During Leg 55 in the International Phase of Ocean Drilling (IPOD) of the Deep Sea Drilling Project (DSDP), the Glomar Challenger drilled 11 holes, including a multiple re-entry hole on Suiko Seamount, at four sites (430 through 433) in the Emperor Seamount chain. Water depths were relatively shallow, and ranged from 1320 to 1874 meters.

Recovery of sedimentary sequences was poor, especially in the older parts of the cored sections. Sediments range from Paleocene through Quaternary, although no Oligocene sediments were found. In many cores, up- or down-hole contamination of the sediments was noted. The sedimentary sequences contain the Paleogene/ Quaternary hiatus at all sites, and also many other hiatuses at Site 433.

All recovered sedimentary cores were studied for calcareous nannofossils, foraminifers, radiolarians, diatoms, and silicoflagellates. Stratigraphic distribution and relative abundances of the various groups of microfossils at four sites drilled during Leg 55 are indicated in Figure 1.

In addition to these investigations by the shipboard paleontologists, other paleontological contributions were solicited, on Tertiary pollen and spores (E. V. Koreneva, this volume), and on Paleogene shallow water microfossils, including ostracodes, bryozoans, and calcareous algae (H. Hagn, A. Butt, and H. Malz, this volume).

\section{SITE 430: ŌJIN SEAMOUNT}

At Hole 430, the upper part of the pebbly mudstone in Core 2 is dated Quaternary on the basis of its diatoms (Figure 2). For the lower part, the nannofossils indicate Zones NP 19 to NP 20 (upper Eocene).

At Hole 430A, both nannofossils and foraminifers indicate that most of the cored sediments are upper Paleocene. Overlying thin sediments contain some Quaternary foraminifers and diatoms.

At Hole 430B, a punch core recovered Quaternary watery ooze.

\section{SITE 431: YŌMEI SEAMOUNT}

At both Hole 431 and Hole 431A, Quaternary nannofossils, foraminifers, radiolarians, and diatoms occur
(Figure 3). Planktonic foraminifers indicate that the oldest sediments at Hole 431A are middle Eocene.

\section{SITE 432: NINTOKU SEAMOUNT}

Microfossils in the pelagic ooze at Hole 432 are all Quaternary, whereas planktonic foraminifers in the fine-grained sand in the basal part indicate a late Paleocene to early Eocene date. (See Figure 4.)

At Hole 432A, the only age indicators found, benthic foraminifers, indicate that the sediments are upper $\mathrm{Pa}$ leocene to lower Eocene.

\section{SITE 433: SUIKO SEAMOUNT}

Core 1 from Hole 433 is Quaternary and Pliocene, judged by its abundant and well-preserved microfossils (Figure 5).

Hole 433A was continuously cored and penetrated 163.5 meters of sedimentary sequences, varying from Quaternary ooze to Paleocene reef sediments. All microfossils are abundant and well preserved throughout the Neogene pelagic section. Nannofossils and foraminifers are very rare and poorly preserved, however, throughout the Paleogene reef sediments. Siliceous fossils are restricted to the Neogene sediments.

A repetition of upper Pliocene and Quaternary calcareous fossil assemblages (determined from both nannofossils and planktonic foraminifers) occurs in Cores 1 and 2 of Hole 433A, but siliceous fossils indicate no repetition.

The Pliocene/Quaternary hiatus occurs in Hole 433, and Pliocene/Quaternary, upper Miocene/Pliocene, middle to lower Miocene/upper Miocene and lower Eocene to upper Paleocene/middle to lower Miocene hiatuses can be recognized at Hole 433A. Most of the Miocene and Eocene, and all of the Oligocene are missing at Hole 433A.

Paleogene nannofossils indicate Zones NP 7 to NP 10 (upper Paleocene to lower Eocene) for Cores 8 and 9, and NP 5 to NP 6 (middle Paleocene) for Cores 10 through 19, in general agreement with the age assignments based on foraminifers.

Poorly preserved nannofossils at Hole 433B and Hole $433 \mathrm{C}$ suggest that the reef carbonate sand is middle $\mathrm{Pa}$ leocene to lower Eocene (Zones NP 5 to NP 10) (Figure $6)$. No other age-diagnostic microfossil species were recovered. 


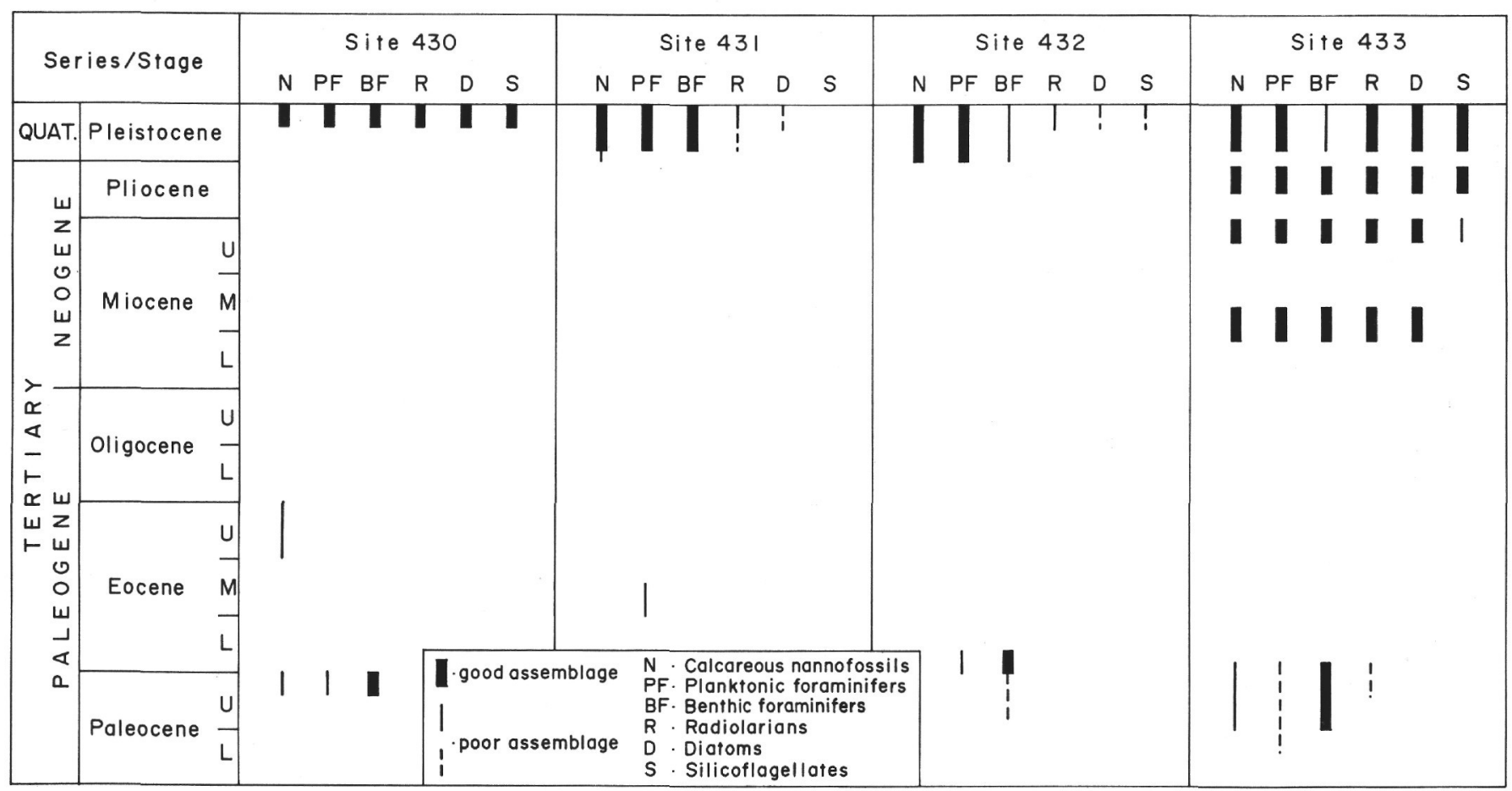

Figure 1. Stratigraphic distribution of microfossil groups at Sites 430 through 433.

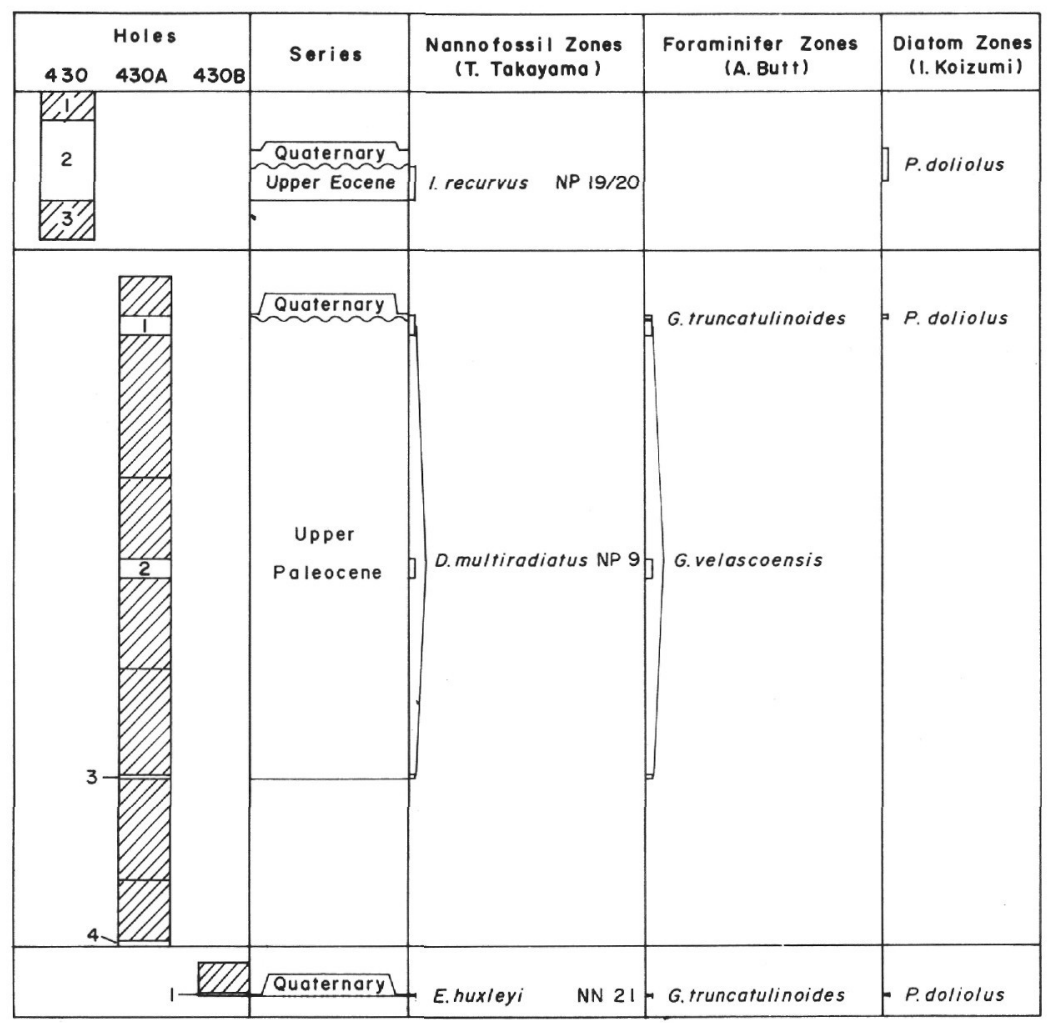

Figure 2. Biostratigraphy of the Cenozoic sediments at Site 430, Ōjin Seamount. 


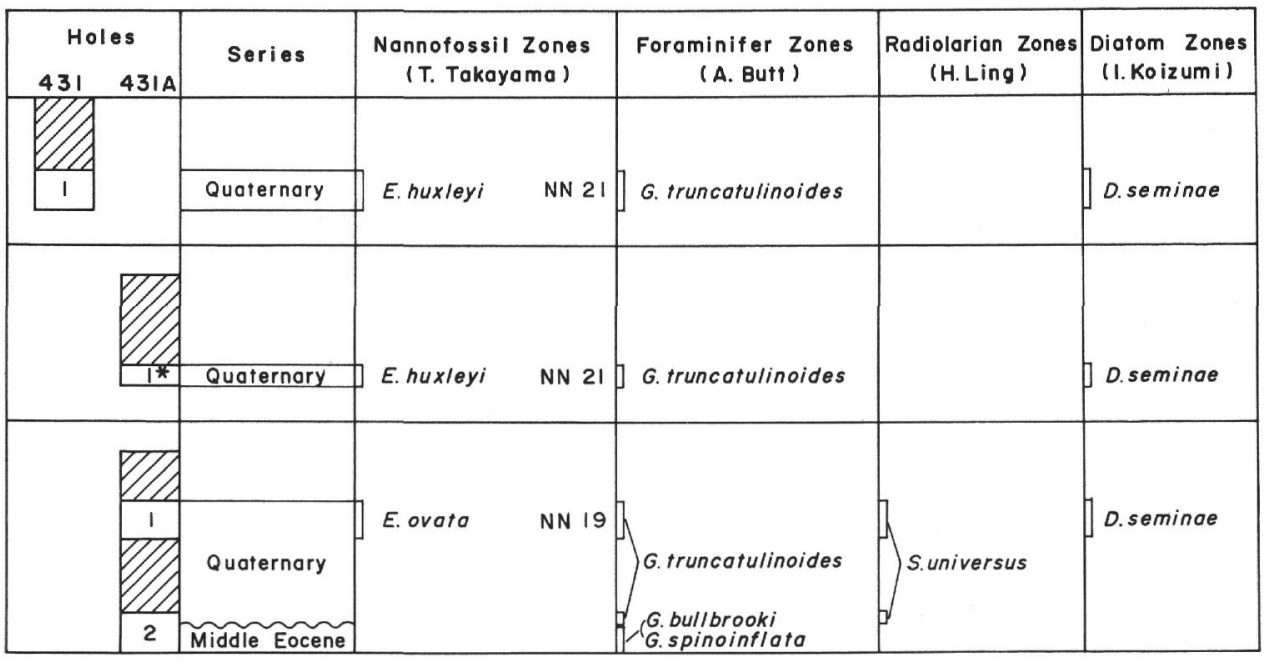

Figure 3. Biostratigraphy of the Cenozoic sediments at Site 431, Yōmei Seamount.

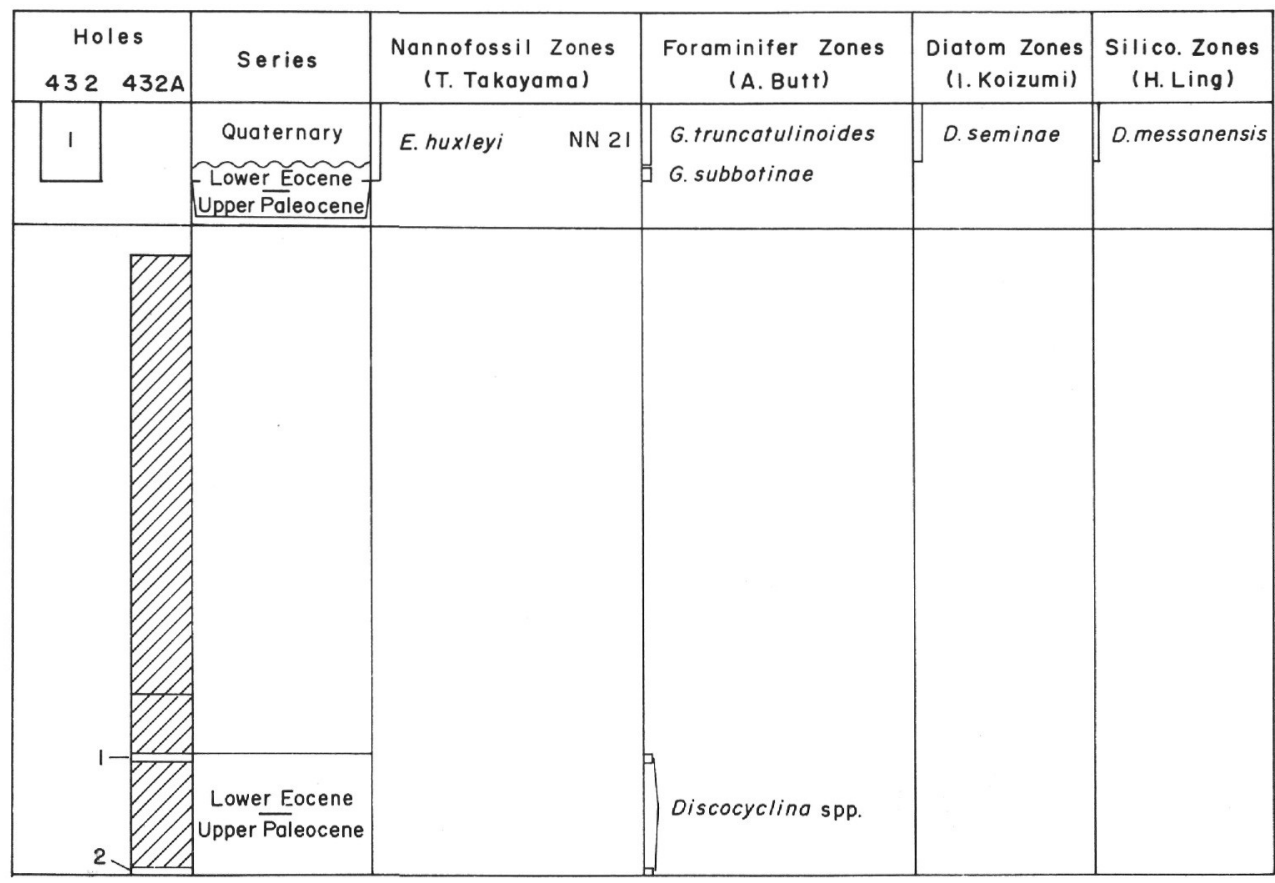

Figure 4. Biostratigraphy of the Cenozoic sediments at Site 432, Nintoku Seamount. 


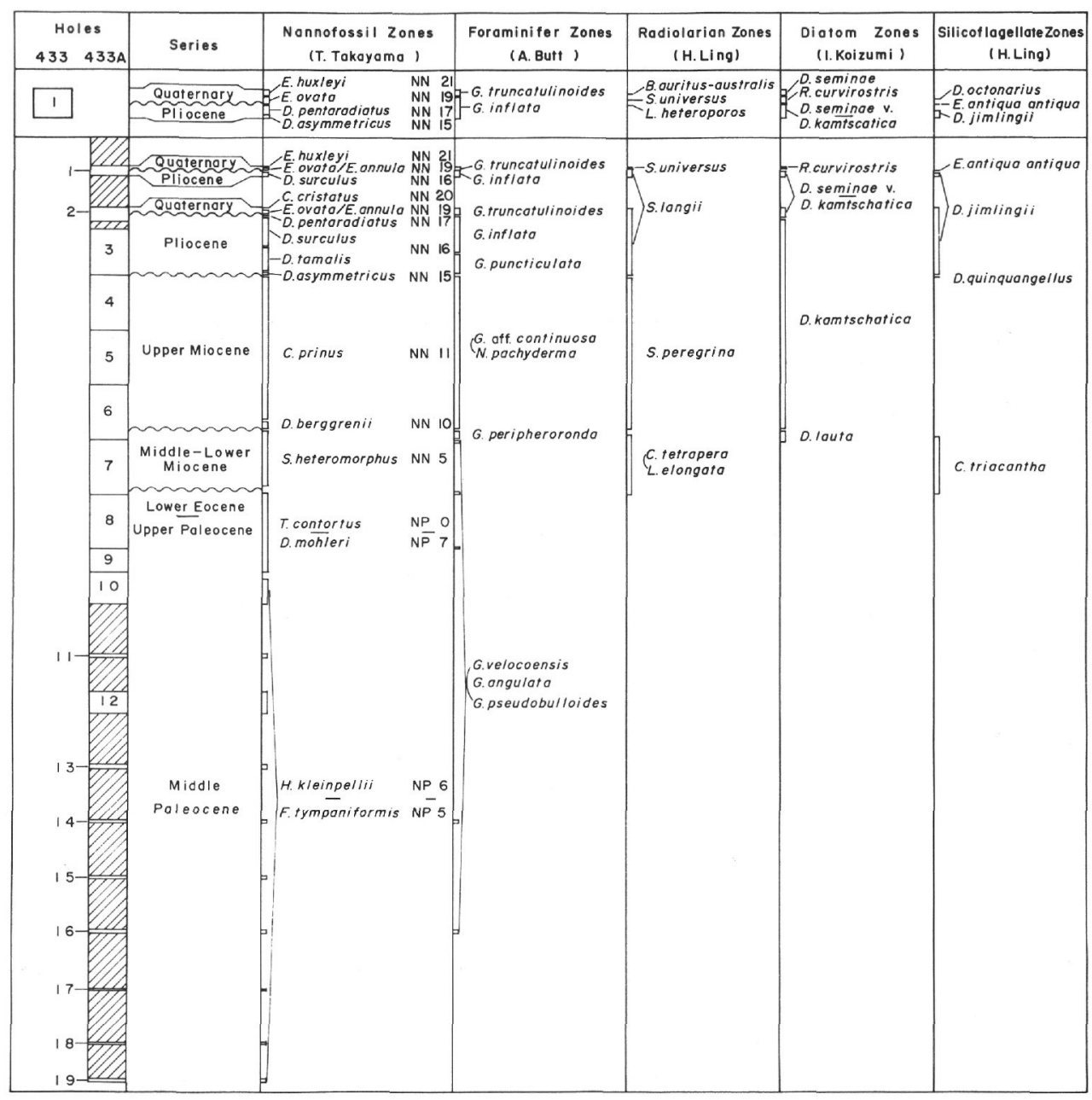

Figure 5. Biostratigraphy of the Cenozoic sediments from Holes 433 and $433 A$, Suiko Seamount.

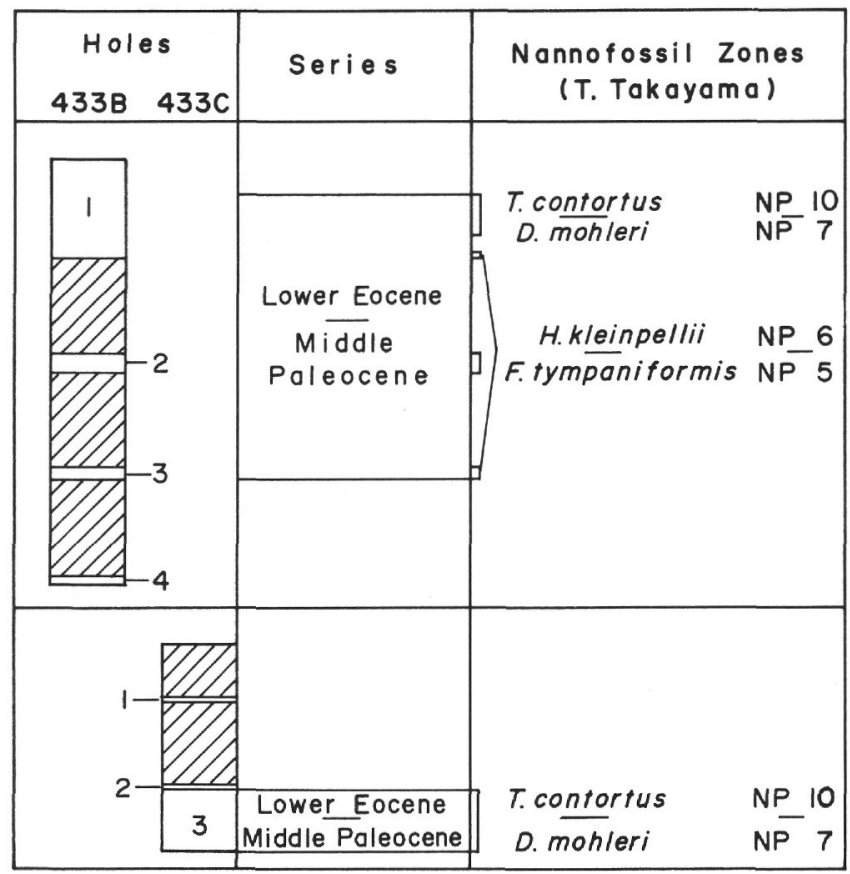

Figure 6. Biostratigraphy of the Paleogene reef sediments from Holes 433B and 433C, Suiko Seamount. 